net). It contains the official commentary on the vital statistics contained in Parts i. and ii., Medical and Civil Tables, already issued. The population at the middle of the year was estimated at $39,806,000$ persons, made up of $19,075,000$ males and $20,731,000$ females, the excess of females being most marked in the age groups between thirty and fifty-five years. The death-rate, 11.4 per 1000 population, is the lowest on record. The deaths ascribed to cancer $(57,883)$ are the highest yet recorded, but when standardised are almost the same as, and no higher than, the preceding year. Attention is directed to the increasing mortality associated with motor-vehicles, and particularly with motor-cycles. During the six years 1925-30, motorcycles were associated with the deaths of 2752 young men between the ages of fifteen and thirty-five years, which is 2.8 times the number killed in the preceding 14 years. The corresponding numbers of young women were 316 and 79 , a fourfold increase.

\section{Grant in Aid of African Research}

A FURTher grant in aid of research in Africa by the trustees of the Rockefeller Foundation is announced. The sum of $£ 3000$ per annum for a period of three years has been granted to the School of Oriental Studies in the University of London for the furtherance of research in African linguistics. This subject is already included in the curriculum of the school as part of the work of the Department of Phonetics and Linguistics, acting in co-operation with the International Institute of African Languages and Cultures. Now that the Oriental Institute has this additional fund at its disposal, it will be possible to extend its activities in this subject especially in the field of original research. It will be remembered that the Rockefeller Foundation is already assisting liberally African research in Great Britain by the grant of $£ 5000$ a year, to be increased in certain contingencies to $£ 10,000$, to the International Institute of African Linguistics and Cultures ; and this grant is being used to meet the cost of a scheme of research which has been planned to cover a period of five years.

\section{Announcements}

Sir William Braga, director of the Royal Institution, left England on June 25 for a lecture tour in South America under the auspices of the IberoAmerican Institute of Great Britain, of which H.H. the Prince of Wales is president. On the previous day Sir William was received by His Highness, who expressed his interest in the tour. Sir William is due at Buenos Ayres on July 15 and leaves there on Aug. 1, when he goes on to Rio de Janeiro, arriving there on Aug. 6 and staying until Aug. 14. At both places he will be the guest of the British Ambassador and will deliver lectures on recent work on X-rays and crystal analysis. Sir William is expected back in England about Aug. 29.

As noted briefly in our issue of June 11, p. 860 , the centenary of the birth of Sir William Crookes fell on June 17. In 1859 he founded the Chemical News, and the issue of that journal for June 17 is very appropriately dedicated to his memory. Lord Rutherford contributes a descriptive article on the artificial transmutation of elements, Sir Harry McGowan has a short article on Crookes's well-known forecast of a world wheat shortage in relation to chemical industry, and other articles deal with various aspects of Crookes's life and scientific work. The issue includes full-page reproductions of photographs of Crookes and Lord Rutherford.

The Medical Research Council announces that, on behalf of the Rockefeller Foundation, it has made the following awards of travelling fellowships for the academic year 1932-33; these fellowships are awarded to graduates who have had some training in research work either in the primary sciences of medicine or in clinical medicine or surgery, and who are likely to profit by a period of work at a chosen centre in America or, in special cases, in Europe, before taking up positions for higher teaching or research in the British Isles :--Mr. C. P. Beattie, Bacteriology Department, University of Edinburgh ; Mr. W.D. W. Brooks, St. Mary's Hospital, London; Dr. Eleanor M. Creak, Maudsley Hospital, London; Mr. I. G. W. Hill, Royal Infirmary, Edinburgh ; Mr. W. A. Mackey, Department of Surgery, University of Glasgow; Mr. D. J. Macmyn, King's College Hospital, London; Dr. J. C. Moir, University College Hospital, London. In view of the high qualifications of so many of the candidates, the Council greatly regrets that it has not been possible to make a larger number of awards.

Messrs. H. K. Lewis and Co., Ltd., 136 Gower Street, W.C.1, have just issued a very useful classified catalogue of books, in new condition, on physics and mathematics. An admirable feature is the insertion of the year of publication of each volume.

UPWARDS of 2000 works dealing with ornithology are offered for sale, at what appear to be reasonable prices, by Messrs. Wheldon and Wesley, Ltd., 2 Arthur Street, W.C.2, in catalogue New Series, No. 28. The catalogue is obtainable free upon application.

Applicatrons are invited for the following appoint ments, on or before the dates mentioned :-A fulltime lecturer in the Department of Building of the Leedis Technical College - The Director of Education, Education Department, Calverley Street, Leeds (July 6). A teacher of metalwork and technical drawing, and an assistant master to teach principally chemistry and mathematics, in the Junior Technical School of the Castleford, Normanton, and District Mining and Technical Institute, Whitwood-M. G. Swaine, Education Offices, Castleford (July 8). An assistant lecturer in mathematics in the University of Birmingham-The Secretary, The University, Birmingham (July 15). A lecturer in pharmacology in the Department of Physiology of the University of Bristol-The Secretary and Registrar, The University, Bristol (July 22). A secretary of the Jamaica Agricultural Society-The Secretary, Jamaica Agricultural Society, 11 North Parade, Kingston, Jamaica, B.W.I. (Sept. 5).

$$
\text { No. } 3270 \text {, Vou. 130] }
$$

